Supporting information for

\title{
Exploring Volatility Properties of Discrete Secondary Organic Aerosol Constituents of $\alpha$-Pinene and Polycyclic Aromatic Hydrocarbons
}

\author{
Zaeem Bin Babar ${ }^{1,2}$, Fawad Ashraf ${ }^{1,3}$, Jun-Hyun Park ${ }^{1}$, Pham Duy Quang \\ Dao $^{4}$, Chan Sik Cho ${ }^{4}$, Ho-Jin Lim, ${ }^{1, *}$ \\ ${ }^{1}$ Department of Environmental Engineering, Kyungpook National University, Daegu 41566, \\ Republic of Korea \\ ${ }^{2}$ Institute of Energy and Environmental Engineering, University of the Punjab, Lahore \\ 54590, Pakistan \\ ${ }^{3}$ Department of Chemical Engineering, COMSATS Institute of Information Technology, \\ Defence Road, Off Raiwind Road, Lahore 54000, Pakistan \\ ${ }^{4}$ Department of Applied Chemistry, Kyungpook National University, Daegu 41566, Republic \\ of Korea
}

*Corresponding author. Tel: 82-53-950-7546; Fax: 82-53-950-6579

Email address: hjlim@knu.ac.kr 


\section{Synthetic Procedures for SOA Constituents}

\section{Synthesis of 3-methylbutane-1,2,3-tricarboxylic acid (3-MBTCA) (4) ${ }^{1}$}

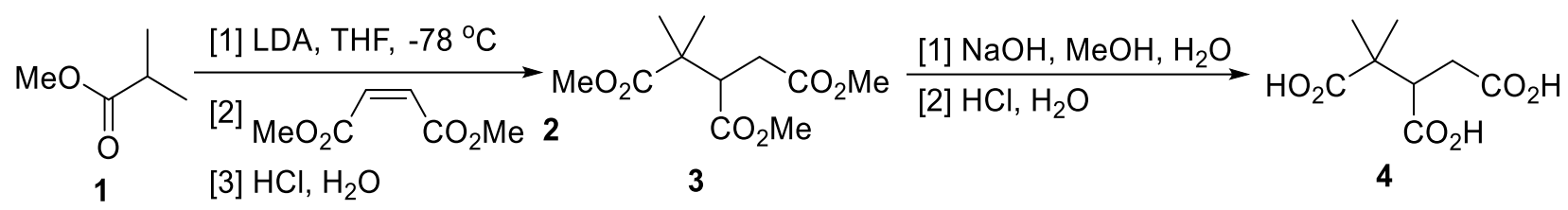

A solution of methyl isobutyrate (1) $(1.02 \mathrm{~g}, 10 \mathrm{mmol})$ in anhydrous tetrahydrofuran $(4 \mathrm{~mL})$ was added to a cooled solution of LDA in THF (2.0 M, $5 \mathrm{~mL})$ at $-70{ }^{\circ} \mathrm{C}$ over $15 \mathrm{~min}$. The colorless solution was stirred for $15 \mathrm{~min}$ at $-70{ }^{\circ} \mathrm{C}$ and a solution of dimethyl maleate

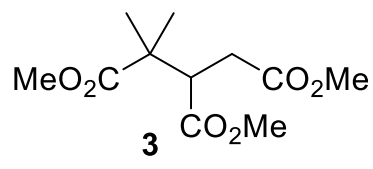

Trimethyl 3-methylbutane1,2,3-tricarboxylate (2) $(1.44 \mathrm{~g}, 10 \mathrm{mmol})$ in anhydrous tetrahydrofuran $(4 \mathrm{~mL})$ was added dropwise over $15 \mathrm{~min}$. Over the course of addition, the reaction mixture changed from colorless to yellow. The reaction mixture was stirred for $30 \mathrm{~min}$ at $-70{ }^{\circ} \mathrm{C}$ and then poured into a cooled $1 \mathrm{M}$ aqueous $\mathrm{HCl}$ solution $(22 \mathrm{~mL})$ and extracted with dichloromethane (3 times x $20 \mathrm{~mL}$ ). Removal of the combined organic solvent under reduced pressure left behind a crude mixture, which was separated by vacuum distillation to give triester 3 (bp $108{ }^{\circ} \mathrm{C} / 15 \mathrm{mmHg}, 1.72 \mathrm{~g}, 70 \%$ ) as a colorless turbid oil. Trimethyl 3-methylbutane-1,2,3-tricarboxylate (3). ${ }^{1} \mathrm{H}$ NMR (500 MHz, $\left.\mathrm{CDCl}_{3}\right) \delta 1.20(\mathrm{~s}, 3 \mathrm{H}), 1.21(\mathrm{~s}, 3 \mathrm{H}), 2.40(\mathrm{dd}, J=16.8$ and $3.3 \mathrm{~Hz}, 1 \mathrm{H}), 2.81(\mathrm{dd}, J=16.8$ and $11.4 \mathrm{~Hz}, 1 \mathrm{H}), 3.32(\mathrm{dd}, J=11.4$ and $3.3 \mathrm{~Hz}, 1 \mathrm{H}), 3.68(\mathrm{~s}, 3 \mathrm{H}), 3.69(\mathrm{~s}, 3 \mathrm{H}), 3.70(\mathrm{~s}, 3 \mathrm{H}) .{ }^{13} \mathrm{C}$ NMR (125 MHz, $\left.\mathrm{CDCl}_{3}\right) \delta 22.3,23.2,32.4,44.0,48.0,51.9$ (x2), 52.2, 172.5, 173.1, 176.4.

Triester 3 (0.74 g, $3 \mathrm{mmol})$ was added to a solution of $\mathrm{NaOH}(1.90 \mathrm{~g}, 48 \mathrm{~mol})$ in $\mathrm{H}_{2} \mathrm{O}(6 \mathrm{~mL})$ and $\mathrm{MeOH}(6 \mathrm{~mL})$ and the mixture was stirred for $4 \mathrm{~h}$ at reflux. The mixture was cooled in an ice bath and acidified with a $1 \mathrm{M}$ aqueous $\mathrm{HCl}$ solution ( $\mathrm{pH}$ 1) until a white solid was formed. The suspension was extracted with dichloromethane (7 times x $10 \mathrm{~mL}$ ), dried over $\mathrm{Na}_{2} \mathrm{SO}_{4}$, and evaporated under reduced pressure to obtain triacid 4 (0.60 g, 98\%)<smiles>CC(C)(C(=O)O)C(CC(=O)O)C(=O)O</smiles>

3-Methylbutane-1,2,3tricarboxylic acid (3-MBTCA) as a white solid. 3-Methylbutane-1,2,3-tricarboxylic acid (4). $\mathrm{Mp} 151-153{ }^{\circ} \mathrm{C}\left(154-155^{\circ} \mathrm{C}^{1 \mathrm{~b}}\right)$. ${ }^{1} \mathrm{H}$ NMR (500 MHz, CD $\left.3 \mathrm{OD}\right) \delta 1.12$ (s, 3H), 1.13 (s, 3H), $2.53(\mathrm{dd}, J=17.0$ and $3.6 \mathrm{~Hz}, 1 \mathrm{H})$, $2.68(\mathrm{dd}, J=17.0$ and $11.5 \mathrm{~Hz}, 1 \mathrm{H}), 3.15(\mathrm{dd}, J=11.5$ and $3.6 \mathrm{~Hz}, 1 \mathrm{H}) .{ }^{13} \mathrm{C} \mathrm{NMR}(125 \mathrm{MHz}$, $\left.\mathrm{CD}_{3} \mathrm{OD}\right) \delta 22.6,23.2,32.9,44.4,49.1,177.2,177.5,181.5$. 
Synthesis of terpenylic acid (7) ${ }^{2-4}$
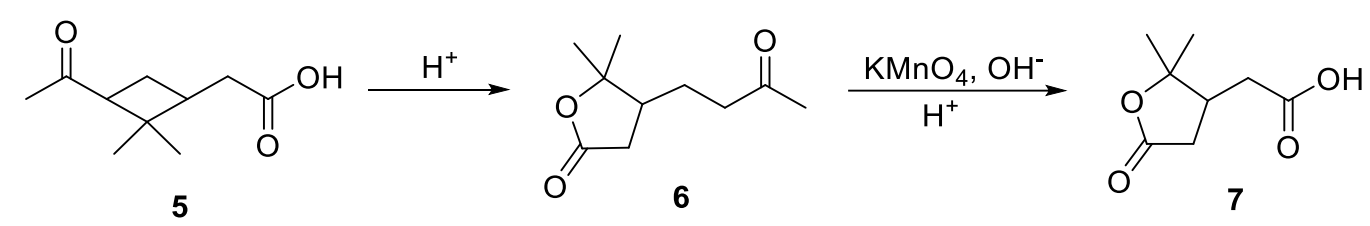

cis-Pinonic acid 5 (2.0 g, $10.9 \mathrm{mmol})$ was dissolved in $42.6 \mathrm{~g}$ of an aqueous $50 \% \mathrm{H}_{2} \mathrm{SO}_{4}$ solution and the mixture was heated for $30 \mathrm{~min}$ at $100{ }^{\circ} \mathrm{C}$. To the resulting brown mixture was added distilled water (60 $\mathrm{mL})$ and the mixture was further saturated with $\left(\mathrm{NH}_{4}\right)_{2} \mathrm{SO}_{4}$. The mixture was extracted with dichloromethane ( 3 times x $20 \mathrm{~mL}$ ), dried over $\mathrm{Na}_{2} \mathrm{SO}_{4}$, and evaporated under reduced pressure to yield

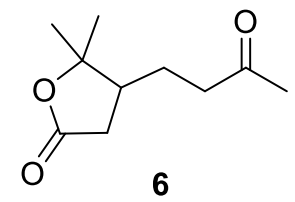

5,5-Dimethyl-4-(3oxobutyl)dihydrofuran $-2(3 H)$-one homoterpenyl methyl ketone 6 (2.0 g, 100\%). 5,5-Dimethyl-4-(3-oxobutyl)dihydrofuran2(3H)-one (6). Mp 61-63 ${ }^{\circ} \mathrm{C}\left(63-64{ }^{\circ} \mathrm{C}^{2 \mathrm{~d}}\right) .{ }^{1} \mathrm{H} \mathrm{NMR}\left(500 \mathrm{MHz}, \mathrm{CDCl}_{3}\right) \delta 1.28(\mathrm{~s}, 3 \mathrm{H}), 1.46(\mathrm{~s}$, $3 \mathrm{H}), 1.50-1.58(\mathrm{~m}, 1 \mathrm{H}), 1.78-1.84(\mathrm{~m}, 1 \mathrm{H}), 2.17$ (s, 3H), 2.18-2.22 (m, 1H), $2.28(\mathrm{dd}, J=16.9$ and $11.6 \mathrm{~Hz}, 1 \mathrm{H}), 2.40-2.54(\mathrm{~m}, 2 \mathrm{H}), 2.59(\mathrm{dd}, J=16.9$ and $7.7 \mathrm{~Hz}, 1 \mathrm{H}) .{ }^{13} \mathrm{C} \mathrm{NMR}(125 \mathrm{MHz}$, $\left.\mathrm{CDCl}_{3}\right) \delta 21.9,23.2,27.4,30.1,34.8,41.8,45.1,86.7,175.2,207.2$.

To homoterpenyl methyl ketone $6(1.5 \mathrm{~g}, 8.1 \mathrm{mmol})$ dissolved in a $0.93 \mathrm{M}$ aqueous $\mathrm{KOH}$ solution $(30 \mathrm{~mL})$, a $0.16 \mathrm{M}$ aqueous $\mathrm{KMnO}_{4}$ solution $(150 \mathrm{~mL})$ was added over $10 \mathrm{~min}$. After removal of the brown precipitate by filtration, the aqueous mixture was acidified with a $10 \%$ aqueous $\mathrm{H}_{2} \mathrm{SO}_{4}$ solution and extracted with diethyl ether. The organic phase was dried over $\mathrm{Na}_{2} \mathrm{SO}_{4}$, evaporated, and recrystallized (hexane/diethyl ether) to give<smiles>CC1(C)OC(=O)CC1CC(=O)O</smiles>
2-(2,2-Dimethyl-5oxotetrahydrofuran-3yl)acetic acid terpenylic acid 7 (1.0 g, 72\%). 2-(2,2-Dimethyl-5-oxotetrahydrofuran-3-yl)acetic acid (7). Mp $89-91{ }^{\circ} \mathrm{C}\left(90{ }^{\circ} \mathrm{C}^{2 \mathrm{e}}\right) .{ }^{1} \mathrm{H} \mathrm{NMR}\left(500 \mathrm{MHz}, \mathrm{CDCl}_{3}\right) \delta 1.30(\mathrm{~s}, 3 \mathrm{H}), 1.48(\mathrm{~s}, 3 \mathrm{H}), 2.38(\mathrm{dd}, J=10.4$ and $17.5 \mathrm{~Hz}, 1 \mathrm{H}), 2.40(\mathrm{dd}, J=10.2$ and $16.2 \mathrm{~Hz}, 1 \mathrm{H}), 2.56(\mathrm{dd}, J=4.7$ and $16.2 \mathrm{~Hz}, 1 \mathrm{H})$, 2.67-2.74 (m, 1H), $2.86(\mathrm{dd}, J=8.2$ and $17.5 \mathrm{~Hz}, 1 \mathrm{H}) .{ }^{13} \mathrm{C} \mathrm{NMR}\left(125 \mathrm{MHz}, \mathrm{CDCl}_{3}\right) \delta 22.2$, $27.3,34.4,35.1,41.3,86.0,175.3,176.5$. 


\section{Synthesis of diaterpenylic acid acetate (DTAA) (12)}

\section{Procedure A $\mathbf{A}^{5,6}$}

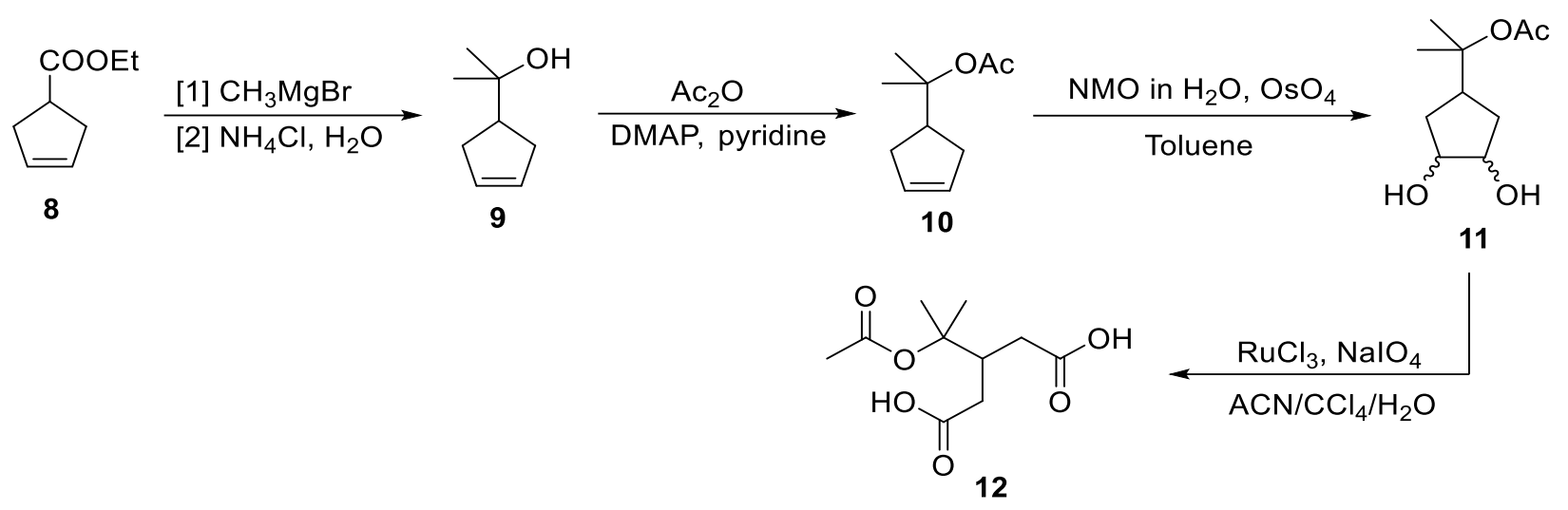

A methyl magnesium bromide solution $(6 \mathrm{~mL}, 3.0 \mathrm{M}$ in diethyl ether) was added dropwise to a solution of ethyl cyclopent-3-ene-1-carboxylate (8) $(0.76 \mathrm{~g}, 6 \mathrm{mmol})$ in diethyl ether $(10 \mathrm{~mL})$ at $0{ }^{\circ} \mathrm{C}$. After the resulting mixture was stirred for $2 \mathrm{~h}$ at $45^{\circ} \mathrm{C}$, a saturated $\mathrm{NH}_{4} \mathrm{Cl}$ aqueous solution $(20 \mathrm{~mL})$ was slowly added into the mixture. The reaction mixture was

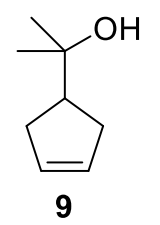

2-(Cyclopent-3-en-1yl)propan-2-ol extracted with ethyl acetate ( 3 times x $20 \mathrm{~mL}$ ), dried oved $\mathrm{Na}_{2} \mathrm{SO}_{4}$, evaporated, and distilled under reduced pressure to yield tertiary alcohol 9 (bp 79-81 ${ }^{\circ} \mathrm{C} / 35 \mathrm{mmHg}, 0.62 \mathrm{~g}, 81 \%$ ). 2(Cyclopent-3-en-1-yl)propan-2-ol (9). ${ }^{1} \mathrm{H} \mathrm{NMR}\left(500 \mathrm{MHz}, \mathrm{CDCl}_{3}\right) \delta 1.19$ (s, 6H), $1.46(\mathrm{~s}, 1 \mathrm{H})$, 2.22-2.29 (m, 2H), 2.34-2.42 (m, 3H), $\left.5.66(\mathrm{~s}, 2 \mathrm{H}) .{ }^{13} \mathrm{C} \mathrm{NMR} \mathrm{(125} \mathrm{MHz,} \mathrm{CDCl}_{3}\right) \delta 27.70$, $34.11,48.72,72.28,129.93$.

4-Dimethylaminopyridine (DMAP) (0.06 g, $0.49 \mathrm{mmol})$ was added to a solution of tertiary alcohol 9 (0.62 g, $4.9 \mathrm{mmol})$ in pyridine $(20 \mathrm{mmol})$ and acetic anhydride (20 mmol), and then stirred overnight at room temperature. The excess acetic anhydride was destroyed by the addition of methanol $(5 \mathrm{~mL})$ and the mixture was neutralized by a $1 \mathrm{M}$ aqueous $\mathrm{HCl}$ solution. The resulting mixture was extracted with diethyl ether (3 times x $20 \mathrm{~mL}$ )

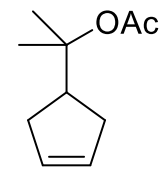

10

2-(Cyclopent-3-en-1yl)propan-2-yl acetate and dried over $\mathrm{Na}_{2} \mathrm{SO}_{4}$. Removal of the solvent left behind a crude mixture, which was separated by vacuum distillation to yield acetate $10\left(0.62 \mathrm{~g}, 76 \%\right.$, bp $\left.84-87^{\circ} \mathrm{C} / 20 \mathrm{mmHg}\right)$. 2(Cyclopent-3-en-1-yl)propan-2-yl acetate (10). ${ }^{1} \mathrm{H} \mathrm{NMR}\left(500 \mathrm{MHz}, \mathrm{CDCl}_{3}\right) \delta 1.45(\mathrm{~s}, 6 \mathrm{H})$, $1.97(\mathrm{~s}, 3 \mathrm{H}), 2.22-2.28(\mathrm{~m}, 2 \mathrm{H}), 2.33-2.40(\mathrm{~m}, 2 \mathrm{H}), 2.70-2.76(\mathrm{~m}, 1 \mathrm{H}) .5 .64-5.67(\mathrm{~m}, 2 \mathrm{H}) .{ }^{13} \mathrm{C}$ 
NMR (125 MHz, $\left.\mathrm{CDCl}_{3}\right) \delta 22.5,23.6,33.9,47.4,84.0,129.8,170.6$.

To the stirred dispersion of acetate $\mathbf{1 0}(0.62 \mathrm{~g}, 3.7 \mathrm{mmol})$ in $20 \mathrm{~mL}$ distilled water, $m$ CPBA $(0.71 \mathrm{~g}, 4.1 \mathrm{mmol})$ was slowly added over 10 $\min$ at $0{ }^{\circ} \mathrm{C}$. After the reaction mixture was stirred for $30 \mathrm{~min}$ at room temperature, a $10 \%$ aqueous $\mathrm{H}_{2} \mathrm{SO}_{4}$ solution $(0.7 \mathrm{~mL})$ was added to the mixture. Additional stirring of the mixture for $2 \mathrm{~h}$ at room temperature was followed by adding solid $\mathrm{NaOH}$ until the mixture became limpid. The mixture was quenched with a saturated aqueous $\mathrm{NaCl}$ solution (15

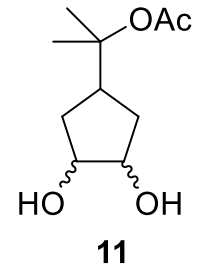

2-(3,4-

Dihydroxycyclopentyl) propan-2-yl acetate $\mathrm{mL}$ ) and extracted with dichloromethane (3 times x $30 \mathrm{~mL}$ ). Drying the organic phase over $\mathrm{Na}_{2} \mathrm{SO}_{4}$ and removal of the solvent gave diol 11 (0.49 g, 65\%), which was used in the next step without further purification. 2-(3,4-Dihydroxycyclopentyl)propan-2-yl acetate (11). ${ }^{1} \mathrm{H}$ NMR $\left(500 \mathrm{MHz}, \mathrm{CDCl}_{3}\right) \delta 1.44(\mathrm{~s}, 6 \mathrm{H}), 1.75-1.78(\mathrm{~m}, 4 \mathrm{H}), 1.96(\mathrm{~s}, 3 \mathrm{H}), 2.62(\mathrm{q}, J=8.8 \mathrm{~Hz}, 1 \mathrm{H})$, 3.15 (br s, 2H), 4.11-4.12 (m, 2H). ${ }^{13} \mathrm{C}$ NMR (125 MHz, $\left.\mathrm{CDCl}_{3}\right) \delta$ 22.4, 23.8, 32.6, 45.6, 74.0, $83.5,170.8$.

To a strongly stirred solution of diol $11(0.69 \mathrm{~g}, 3.4 \mathrm{mmol})$ in acetonitrile/ $/ \mathrm{CCl}_{4} / \mathrm{H}_{2} \mathrm{O}(2: 2: 3,40 \mathrm{~mL}), \mathrm{NaIO}_{4}(2.97 \mathrm{~g}, 13.9 \mathrm{mmol})$ was added. The mixture was stirred for $10 \mathrm{~min}$ at room temperature. After adding $\mathrm{RuCl}_{3} \cdot x \mathrm{H}_{2} \mathrm{O}(0.016 \mathrm{~g}, 0.075 \mathrm{mmol})$ to the mixture and stirring for an additional $2 \mathrm{~h}$ at room temperature, the reaction mixture was<smiles>[R2]C(=O)CC(CC(=O)O)C(C)(C)OC(C)=O</smiles>

3-(2-Acetoxypropan-2yl)pentanedioic acid diluted with water, extracted with dichloromethane ( 3 times x $40 \mathrm{~mL}$ ), and dried over $\mathrm{Na}_{2} \mathrm{SO}_{4}$. Removal of the solvent left behind a crude mixture, which was filtered through a short pad of celite using diethyl ether. Purification by recrystallization (hexane/diethyl ether) gave DTAA 12 (0.55 g, 70\%). 3-(2-Acetoxypropan-2-yl)pentanedioic acid (DTAA) (12). Mp 166-167 ${ }^{\circ} \mathrm{C}$. ${ }^{1} \mathrm{H}$ NMR (500 MHz, DMSO) $\delta 1.38$ (s, 6H), 1.88 (s, 3H), 2.13 (dd, $J=15.9$ and 7.4 Hz, 2H), $2.37(\mathrm{dd}, J=15.9$ and $5.6 \mathrm{~Hz}, 2 \mathrm{H}), 2.73-2.80(\mathrm{~m}, 1 \mathrm{H}), 12.11$ (br s, $2 \mathrm{H}) .{ }^{13} \mathrm{C}$ NMR $(125 \mathrm{MHz}$, $\left.\mathrm{CDCl}_{3}\right) \delta 22.0,23.0,35.0,40.5,83.2,169.5,173.7$. 


\section{Procedure B $^{7}$}<smiles>CCOC(=O)C1[C+]C=CC1</smiles>

To a stirred solution of acetate $\mathbf{1 0}(0.5 \mathrm{~g}, 3.0 \mathrm{mmol})$ in acetonitrile $/ \mathrm{H}_{2} \mathrm{O}$ $(1: 3,20 \mathrm{~mL})$, oxone $(1.84 \mathrm{~g}, 6 \mathrm{mmol})$ and sodium periodate $(0.96 \mathrm{~g}$, $4.5 \mathrm{mmol}$ ) were added. The reaction mixture was vigorously stirred for $24 \mathrm{~h}$ at room temperature. The mixture was filtered, extracted with diethyl ether ( $20 \mathrm{~mL} \times 3$ times), and dried over $\mathrm{Na}_{2} \mathrm{SO}_{4}$. Evaporation of the solvent left behind a crude mixture, which was purified by<smiles>[R2]C(=O)CC(CC(=O)O)C(C)(C)OC(C)=O</smiles>

3-(2-Acetoxypropan-2yl)pentanedioic acid recrystallization (hexane/diethyl ether) to give DTAA 12 (0.54 g, 77\%). 
Synthesis of sodium $(1 R, 2 R, 3 S, 5 R)-2$-hydroxy-2,6,6-trimethylbicyclo[3.1.1]heptan-3-yl sulfate (15) ${ }^{8-11}$

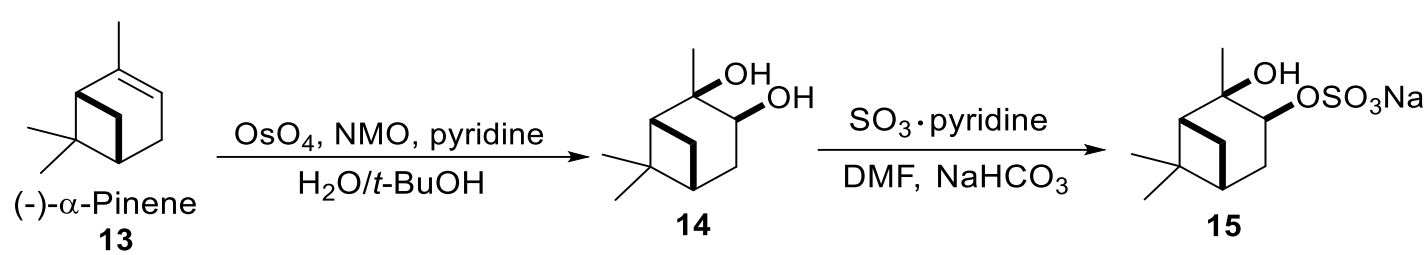

To (-)- $\alpha$-pinene $13(1.36 \mathrm{~g}, 10 \mathrm{mmol})$ in a $50 \mathrm{~mL}$ round-bottom flask was added 4methylmorpholine-N-oxide $(1.76 \mathrm{~g}, 15 \mathrm{mmol})$ and pyridine $(0.78 \mathrm{~mL})$ in a mixture of water $(3.1 \mathrm{~mL})$ and $t-\mathrm{BuOH}(15.4 \mathrm{~mL})$. After adding a solution of $\mathrm{OsO}_{4}(0.34 \mathrm{~mL}, 2.5 \%$ in $t-\mathrm{BuOH})$ to the mixture, it was heated for $48 \mathrm{~h}$ at reflux. Then, the mixture was quenched with a saturated aqueous solution of $\mathrm{NaHSO}_{3}(35 \mathrm{~mL})$ and stirred for $30 \mathrm{~min}$

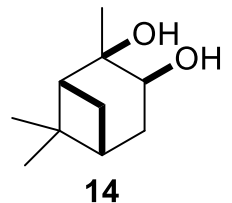

$(1 R, 2 R, 3 S, 5 R)-2,6,6-$ Trimethylbicyclo[3.1.1 Jheptane-2,3-diol at room temperature. The mixture was extracted with dichloromethane ( 3 times x $50 \mathrm{~mL}$ ), dried over $\mathrm{Na}_{2} \mathrm{SO}_{4}$, and purified by column chromatography using hexane/ethyl acetate (1:8) to yield diol 14 (1.46 g, 85\%). (1R,2R,3S,5R)-2,6,6-Trimethylbicyclo[3.1.1]heptane-2,3-diol (14). Mp $55-56{ }^{\circ} \mathrm{C}\left(52-54{ }^{\circ} \mathrm{C}^{4 \mathrm{~d}}\right) .{ }^{1} \mathrm{H}$ NMR $\left(500 \mathrm{MHz}, \mathrm{CDCl}_{3}\right) \delta 0.94(\mathrm{~s}, 3 \mathrm{H}), 1.27(\mathrm{~s}, 3 \mathrm{H}), 1.31(\mathrm{~s}, 3 \mathrm{H})$, $1.37(\mathrm{~d}, J=10.4 \mathrm{~Hz}, 1 \mathrm{H}), 1.64(\mathrm{ddd}, J=2.2,4.8$ and $13.9 \mathrm{~Hz}, 1 \mathrm{H}), 1.91-1.94(\mathrm{~m}, 1 \mathrm{H}), 2.01$ (t, $J=5.8 \mathrm{~Hz}, 1 \mathrm{H}), 2.18-2.23(\mathrm{~m}, 1 \mathrm{H}), 2.43-2.63(\mathrm{~m}, 1 \mathrm{H}), 4.00(\mathrm{dd}, J=4.8$ and $7.7 \mathrm{~Hz}, 1 \mathrm{H})$.

To the dissolved solution of diol $14(0.90 \mathrm{~g}, 5 \mathrm{mmol})$ in dimethylformamide $(5 \mathrm{~mL})$ was added $\mathrm{SO}_{3}-\mathrm{Py}(0.80 \mathrm{~g}, 5 \mathrm{mmol})$. After the mixture was stirred for $4 \mathrm{~h}$ at room temperature, $\mathrm{NaHCO}_{3}(0.84 \mathrm{~g}$, $10 \mathrm{mmol}$ ) was added to the mixture. The resulting mixture was further stirred for $12 \mathrm{~h}$ at $50{ }^{\circ} \mathrm{C}$. Removal of the solvent under reduced pressure left behind a crude mixture that was purified by column

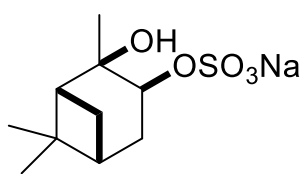

15

Sodium $(1 R, 2 R, 3 S, 5 R)-$ 2-hydroxy-2,6,6trimethylbicyclo[3.1.1] heptan-3-yl sulfate chromatography using gradient eluents (hexane/ethyl acetate $=2: 1$ to dichloromethane/methanol $=15: 1)$ to give organosulfate $15(1.23 \mathrm{~g}, 90 \%)$ as a white solid. Sodium (1R,2R,3S,5R)-2-hydroxy-2,6,6-trimethylbicyclo[3.1.1]heptan-3-yl sulfate (15). Mp $>300{ }^{\circ} \mathrm{C} .{ }^{1} \mathrm{H}$ NMR $\left(500 \mathrm{MHz}, \mathrm{CD}_{3} \mathrm{OD}\right) \delta 1.00(\mathrm{~s}, 3 \mathrm{H}), 1.29$ (s, 3H), 1.37 (s, 3H), 1.55 (d, $J=$ $10.3 \mathrm{~Hz}, 1 \mathrm{H}), 1.87-1.96(\mathrm{~m}, 3 \mathrm{H}), 2.16-2.21(\mathrm{~m}, 1 \mathrm{H}), 2.51-2.56(\mathrm{~m}, 1 \mathrm{H}), 4.74(\mathrm{dd}, J=5.8$ and $9.8 \mathrm{~Hz}, 1 \mathrm{H}) .{ }^{13} \mathrm{C} \mathrm{NMR}\left(125 \mathrm{MHz}, \mathrm{CD}_{3} \mathrm{OD}\right) \delta 24.6,28.4,29.2,30.1,36.7,39.5,41.8,55.4,75.1$, 77.5 


\section{${ }^{1} \mathrm{H}$ and ${ }^{13} \mathrm{C}$ NMR Spectra of Synthesized SOA Constituents}

${ }^{1} \mathrm{H}(500 \mathrm{MHz})$ and ${ }^{13} \mathrm{C}$ NMR (125 MHz) spectra were recorded on a Bruker Avance Digital 500 spectrometer using TMS as an internal standard in $\mathrm{CDCl}_{3}, \mathrm{MeOD}$, or DMSO- $d_{6}$.

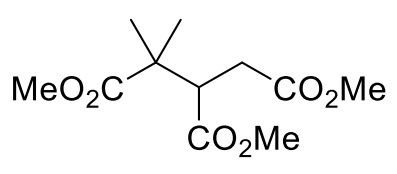

3

\section{$\stackrel{\substack{\infty \\ \stackrel{n}{N}}}{i}$}

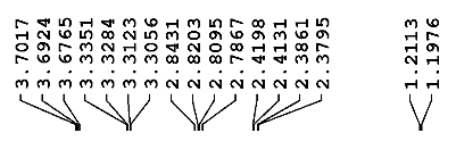

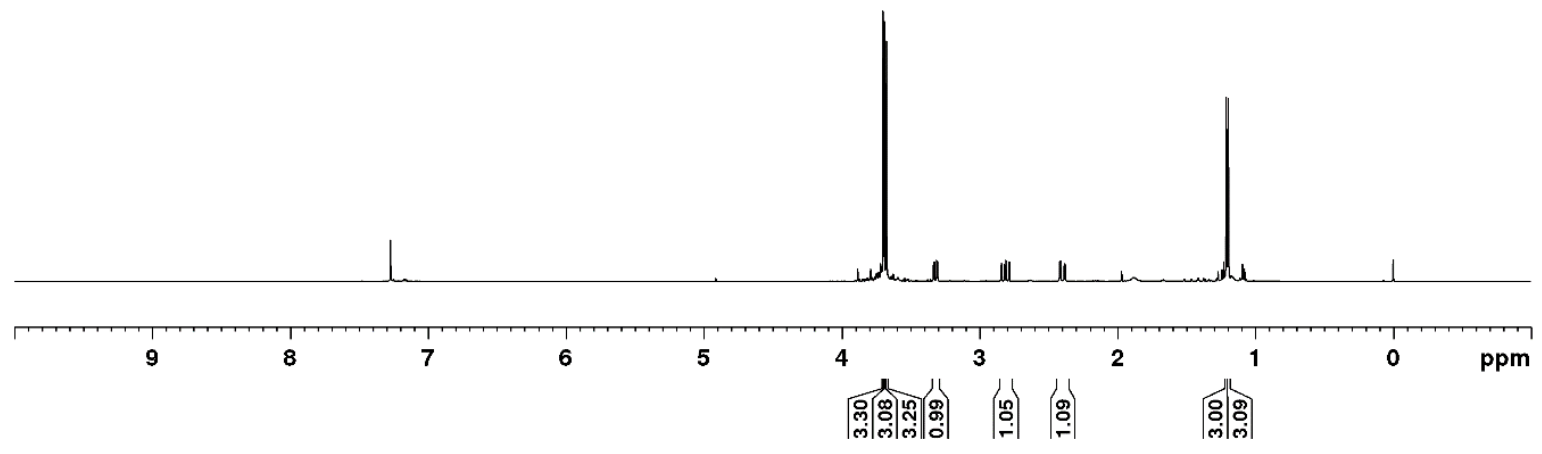




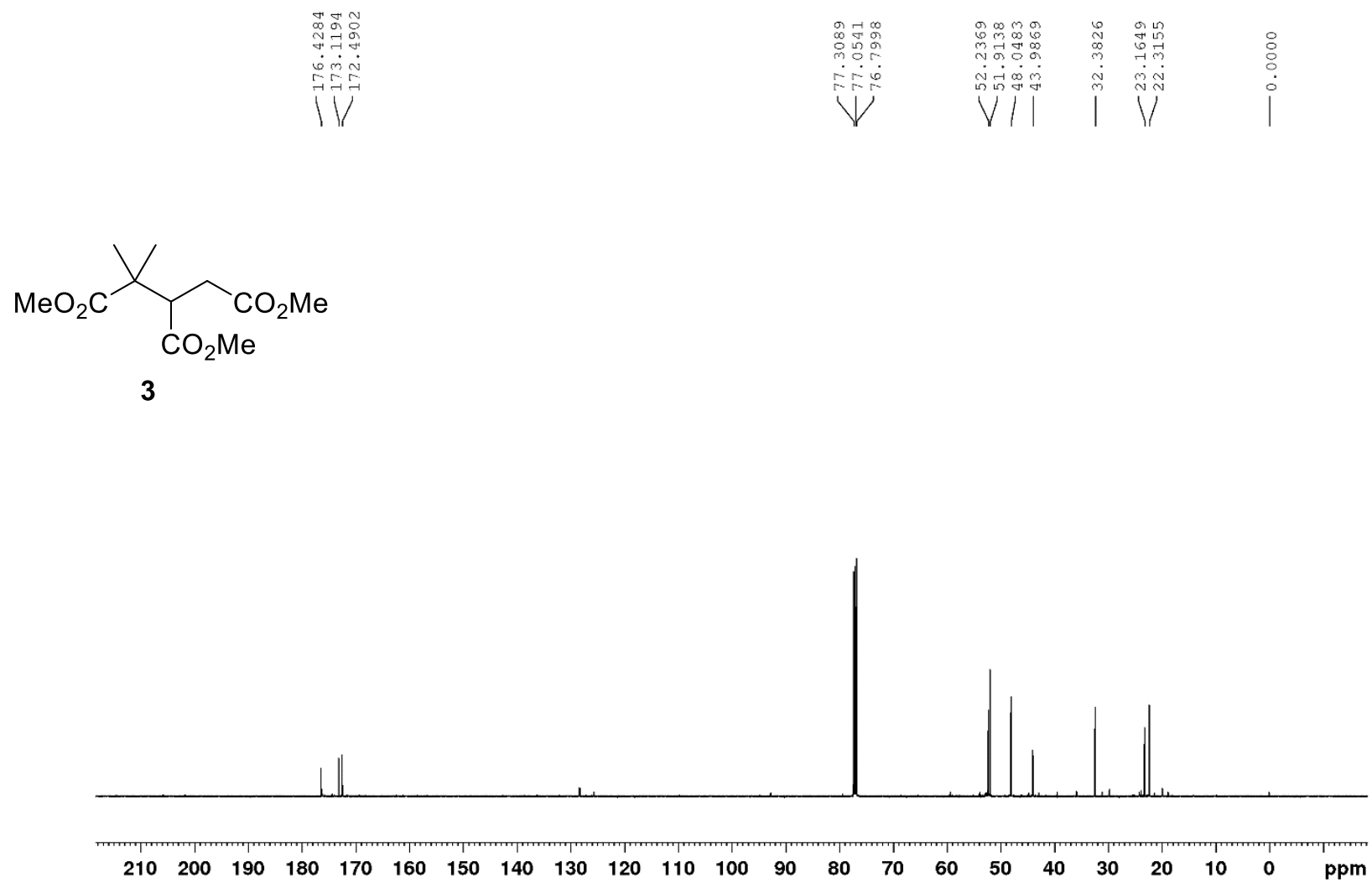




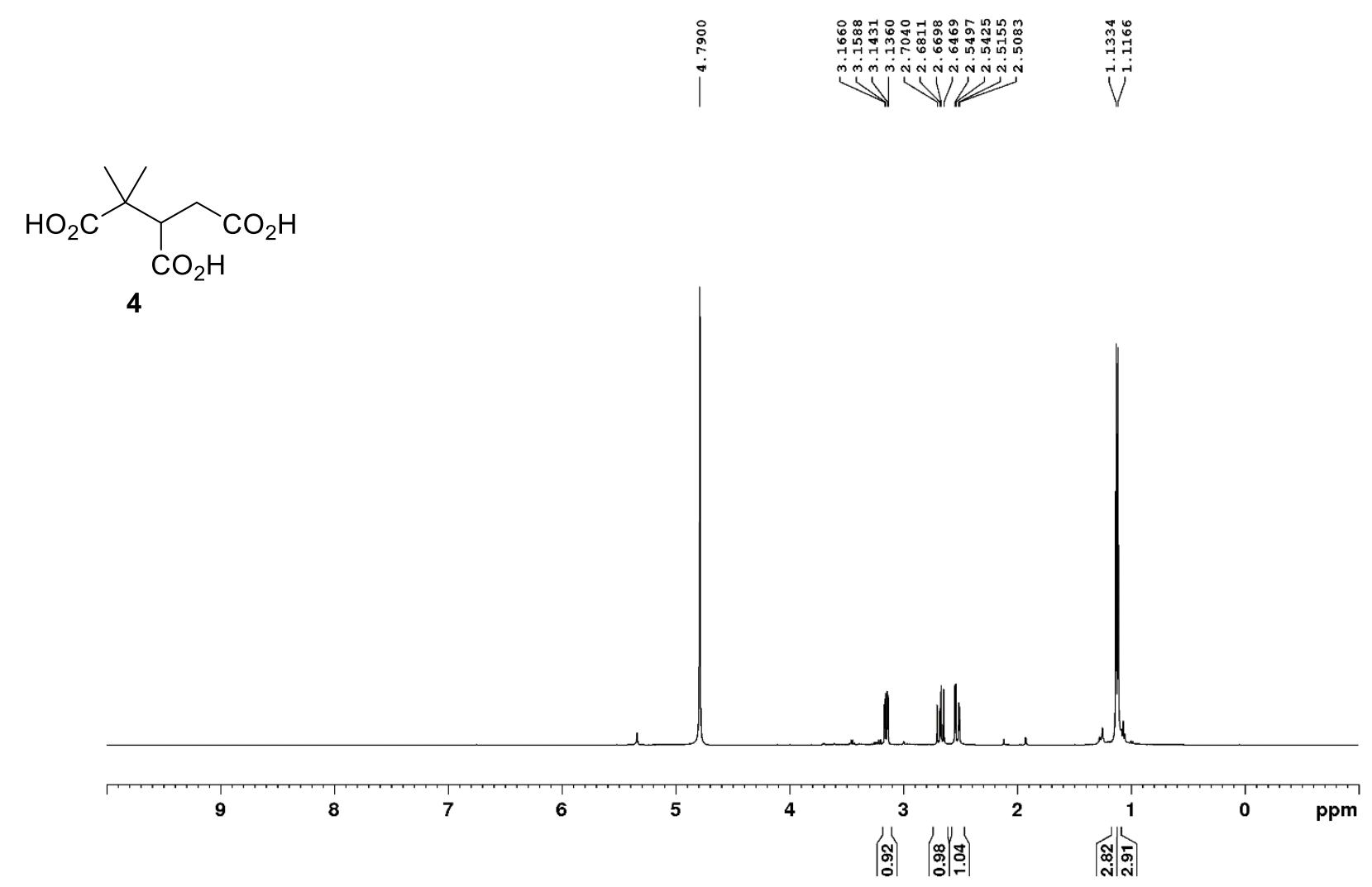




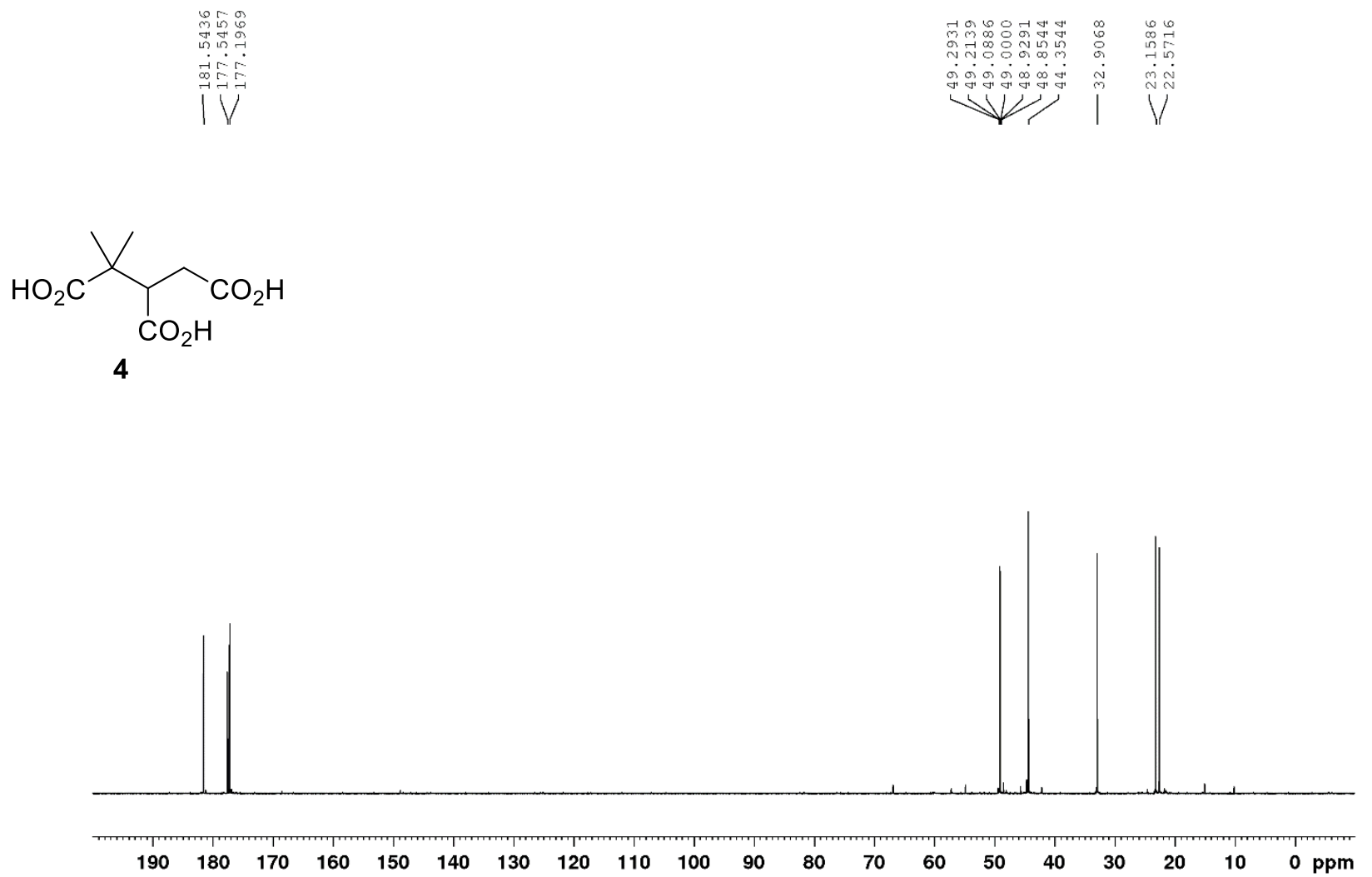

莫

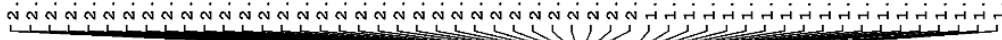

$\sum_{0}^{X}$

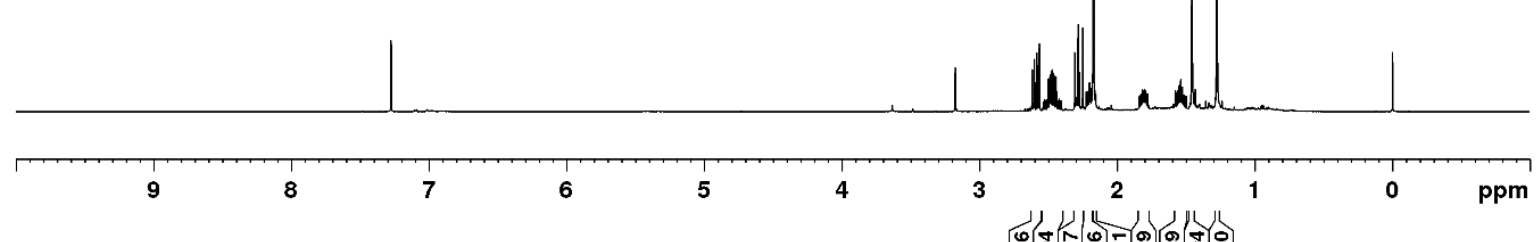

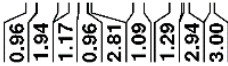




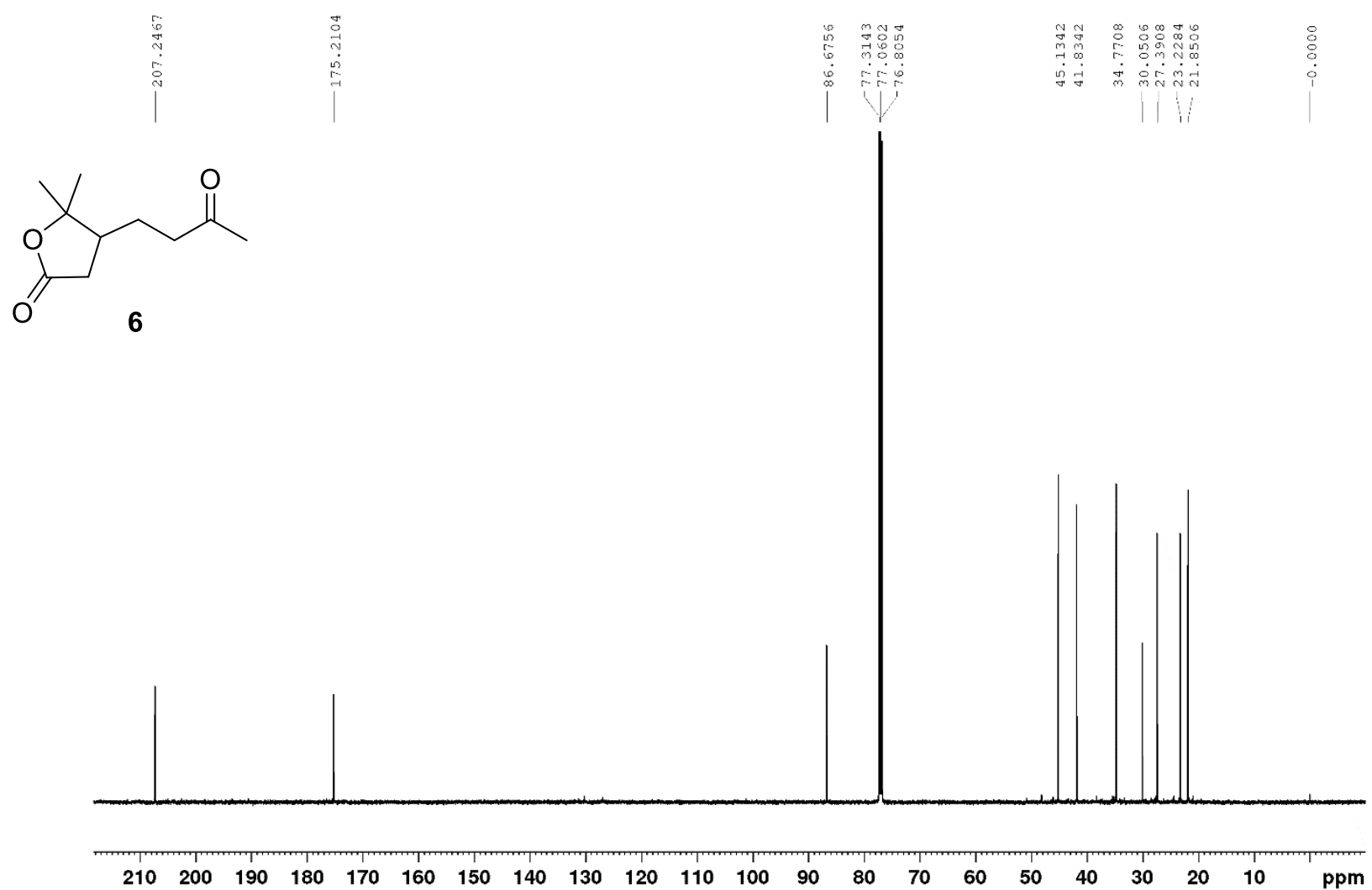


$\sum_{0}^{Y_{7}}$

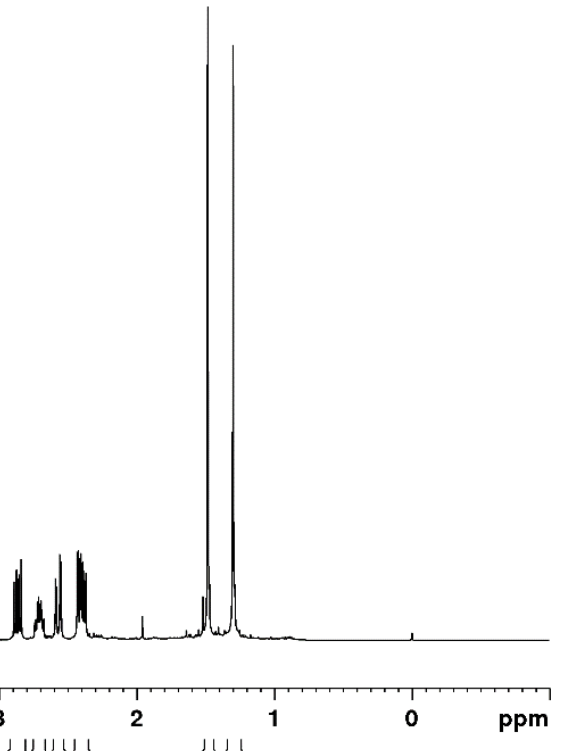

r.yy:

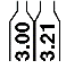




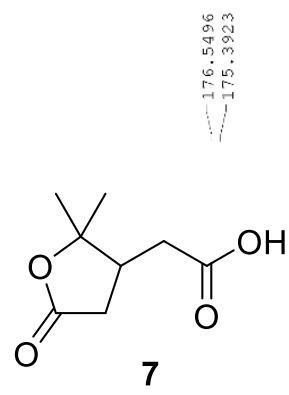

$\begin{array}{lll}r & \\ 0 & 0 \\ \infty & 0 & 0 \\ 0 & 0 & 0 \\ 0 & 0 & 0 \\ 0 & 0 & 0 \\ 0 & 0 & 0 \\ \infty & 0 & 0\end{array}$

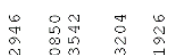

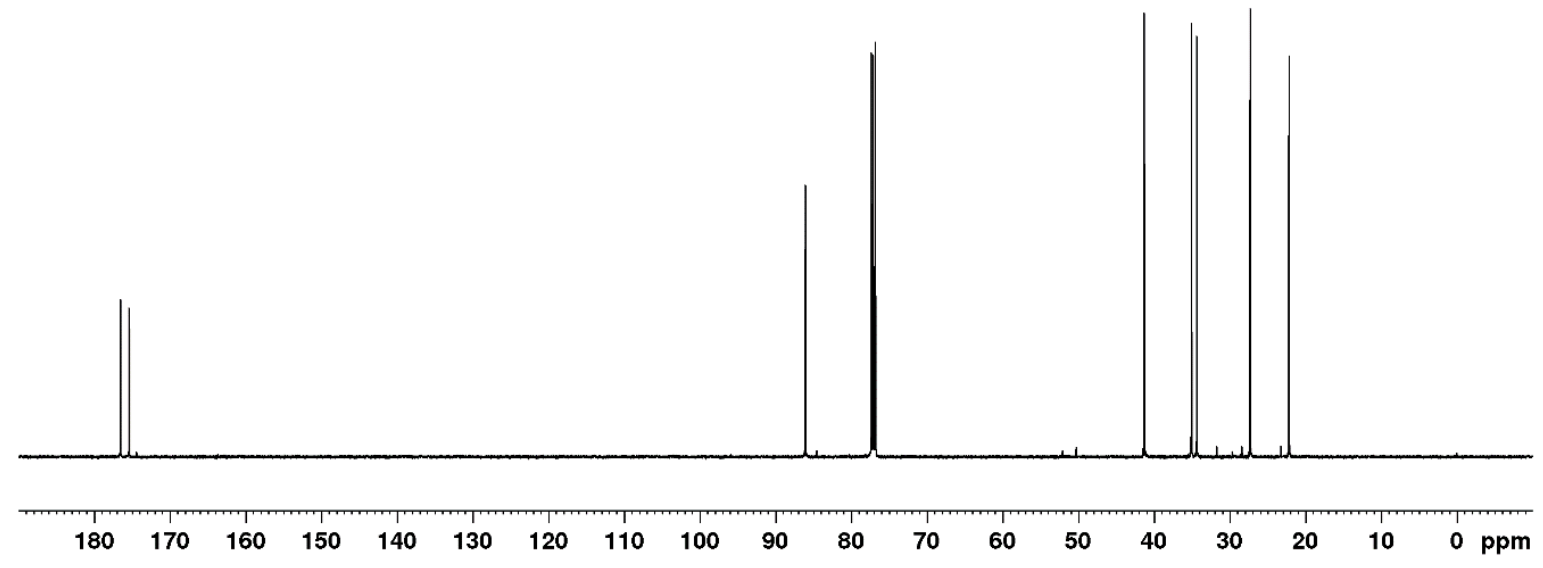




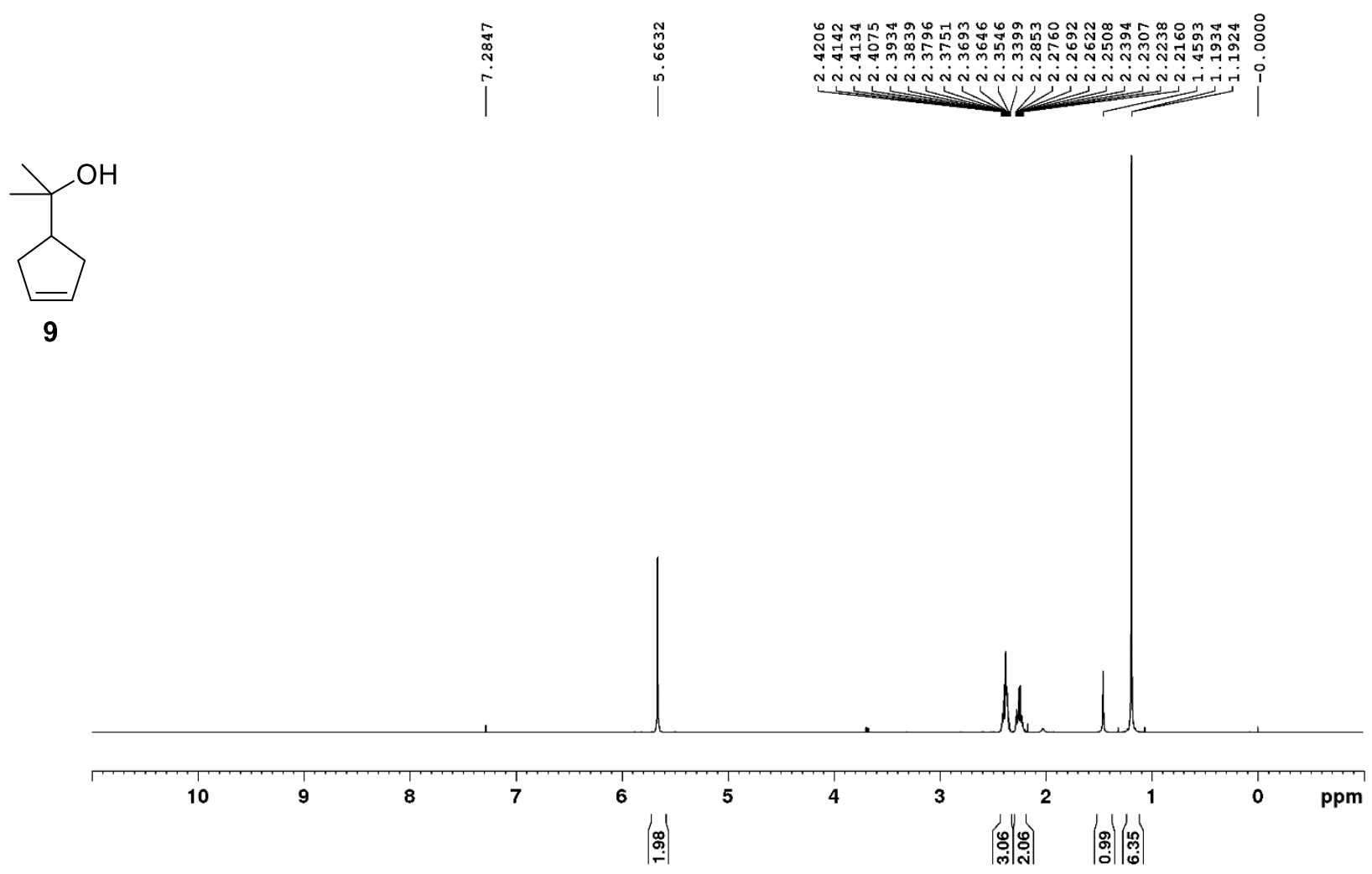




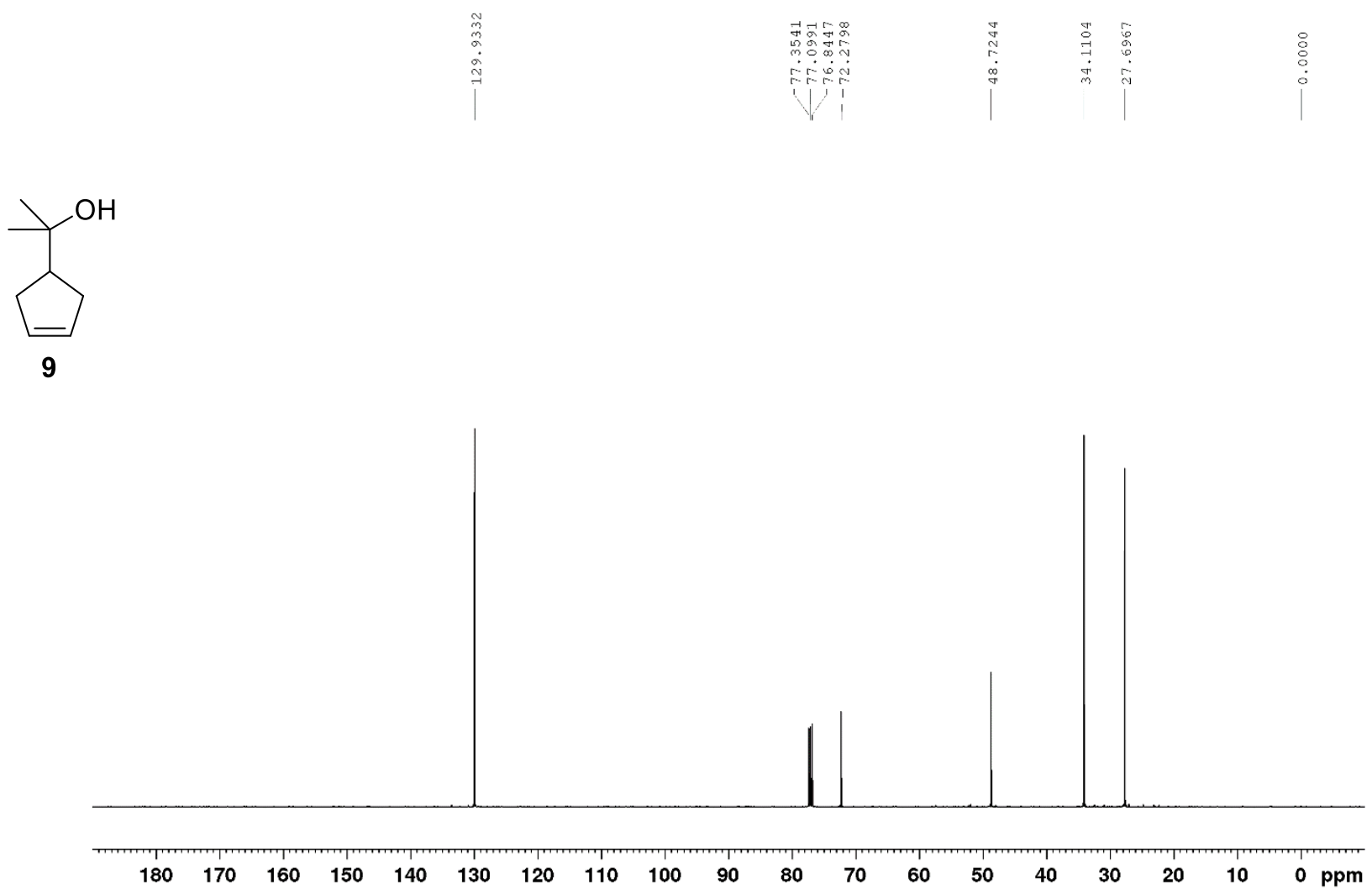




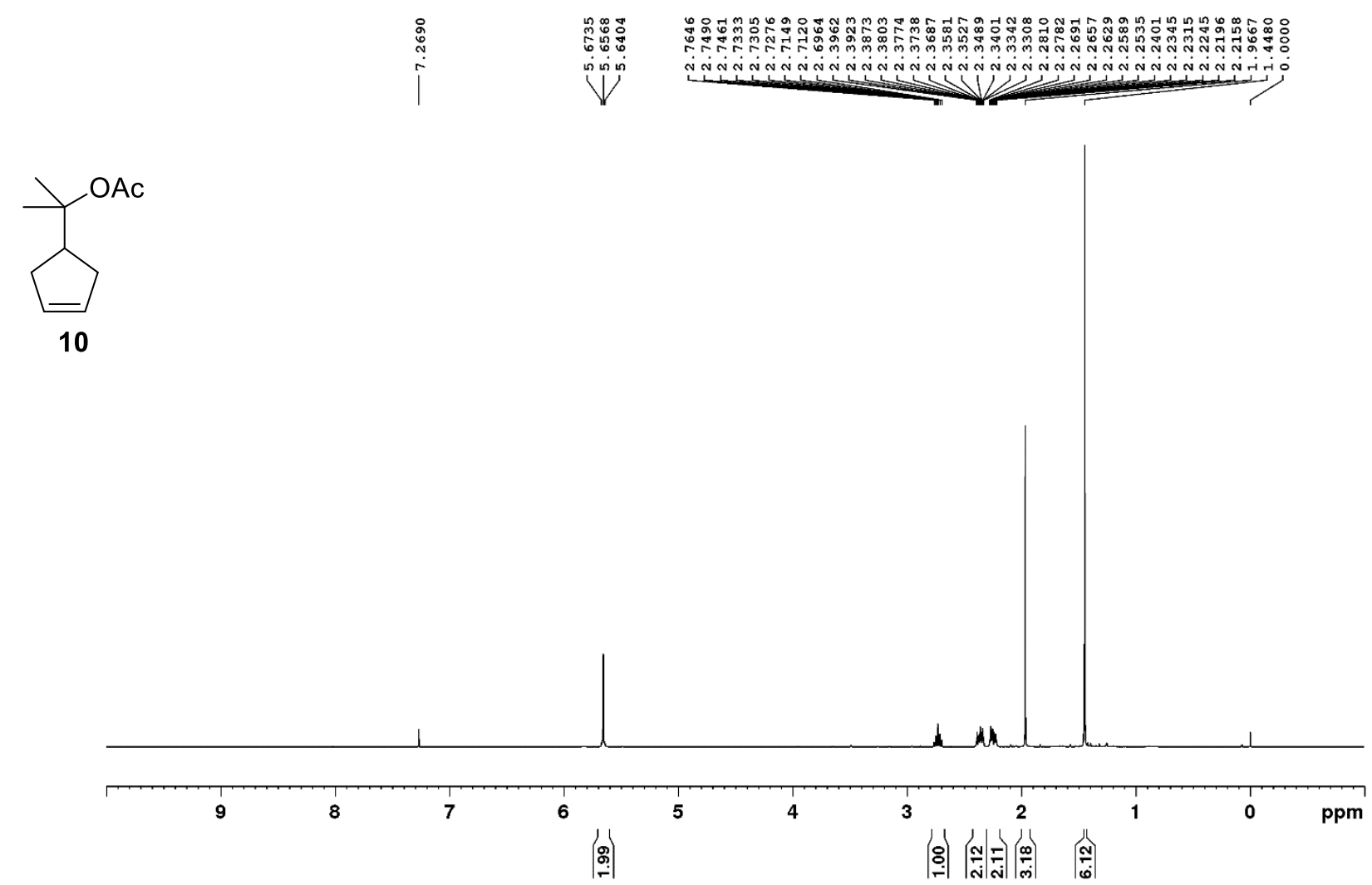




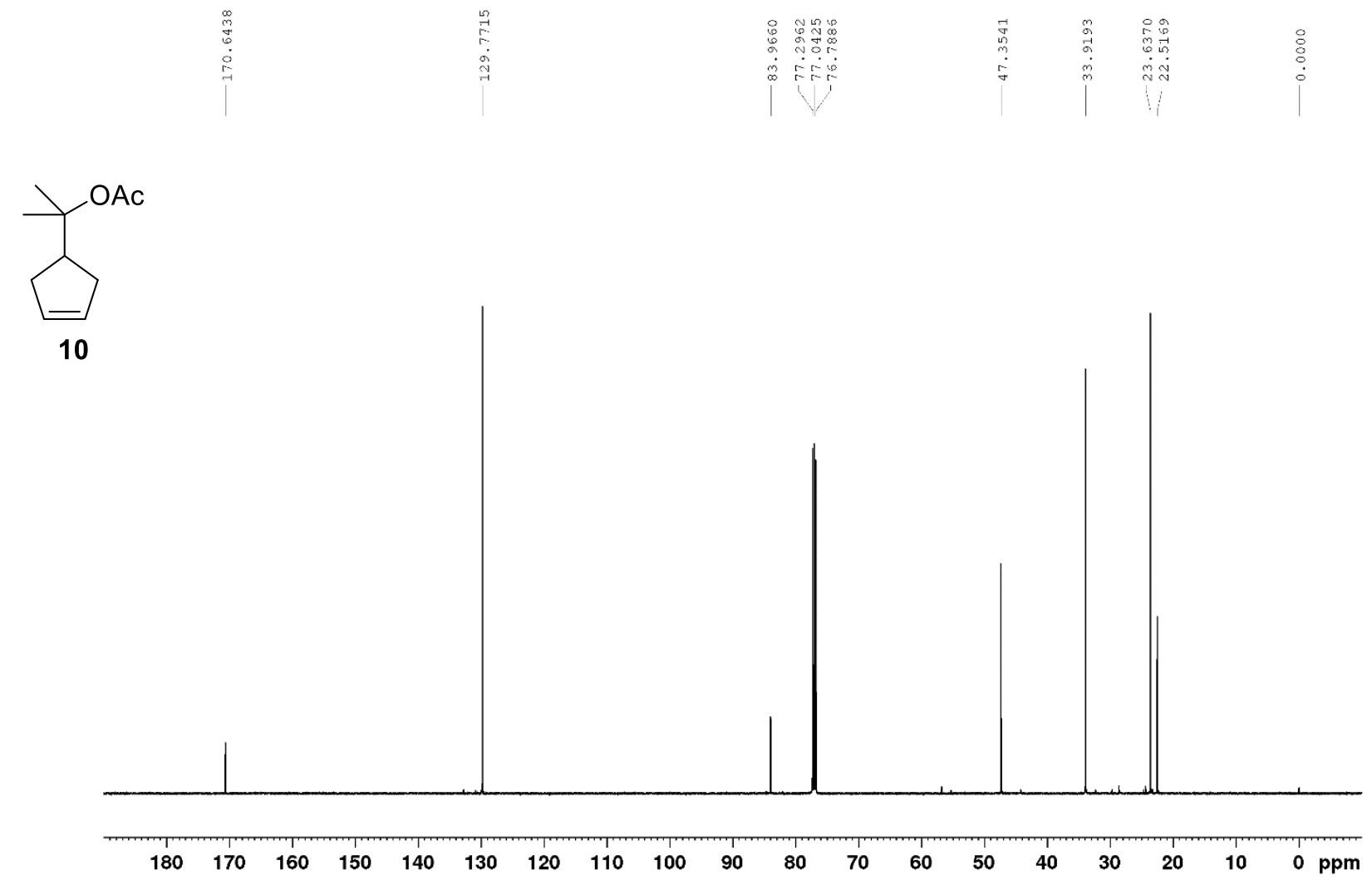



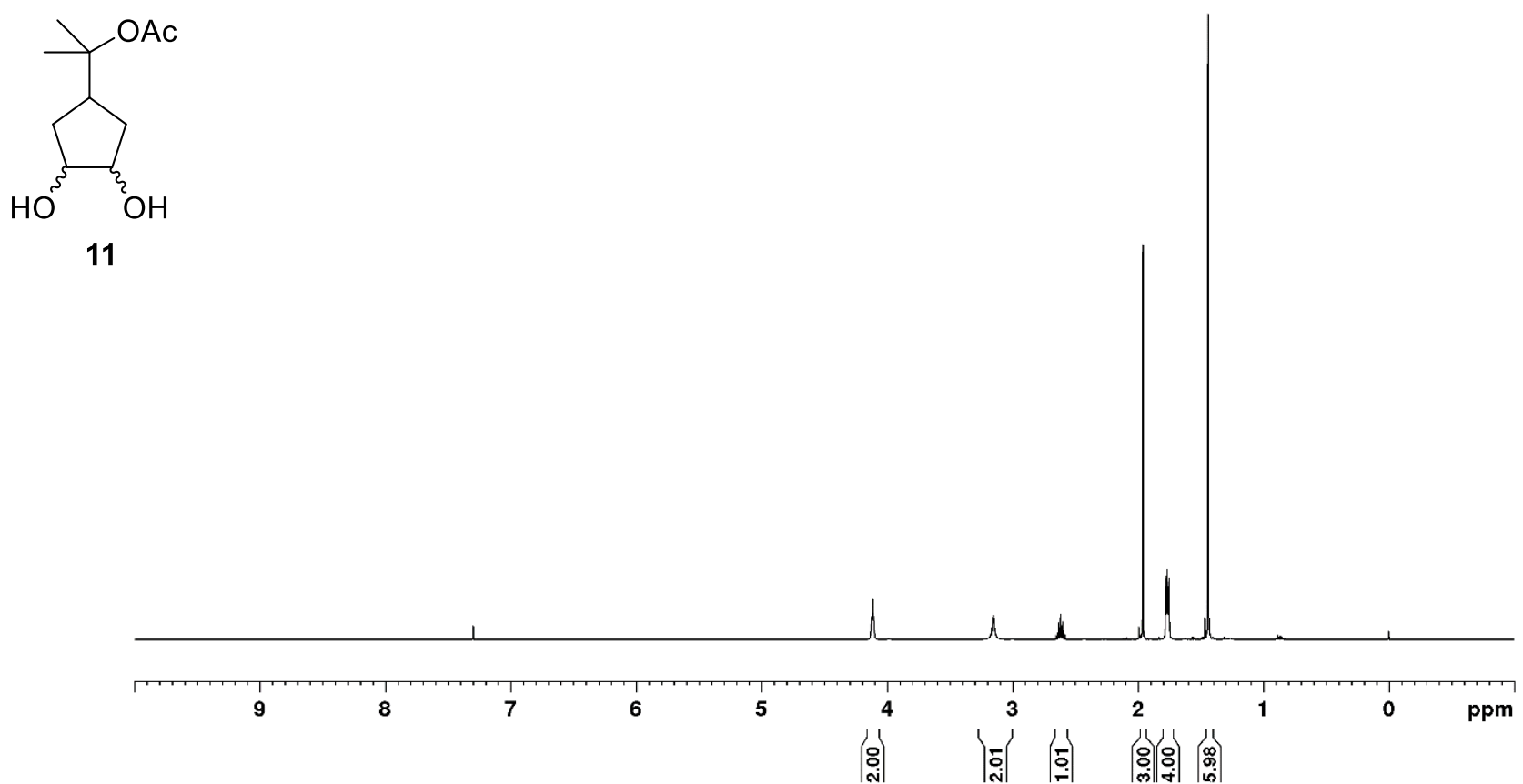


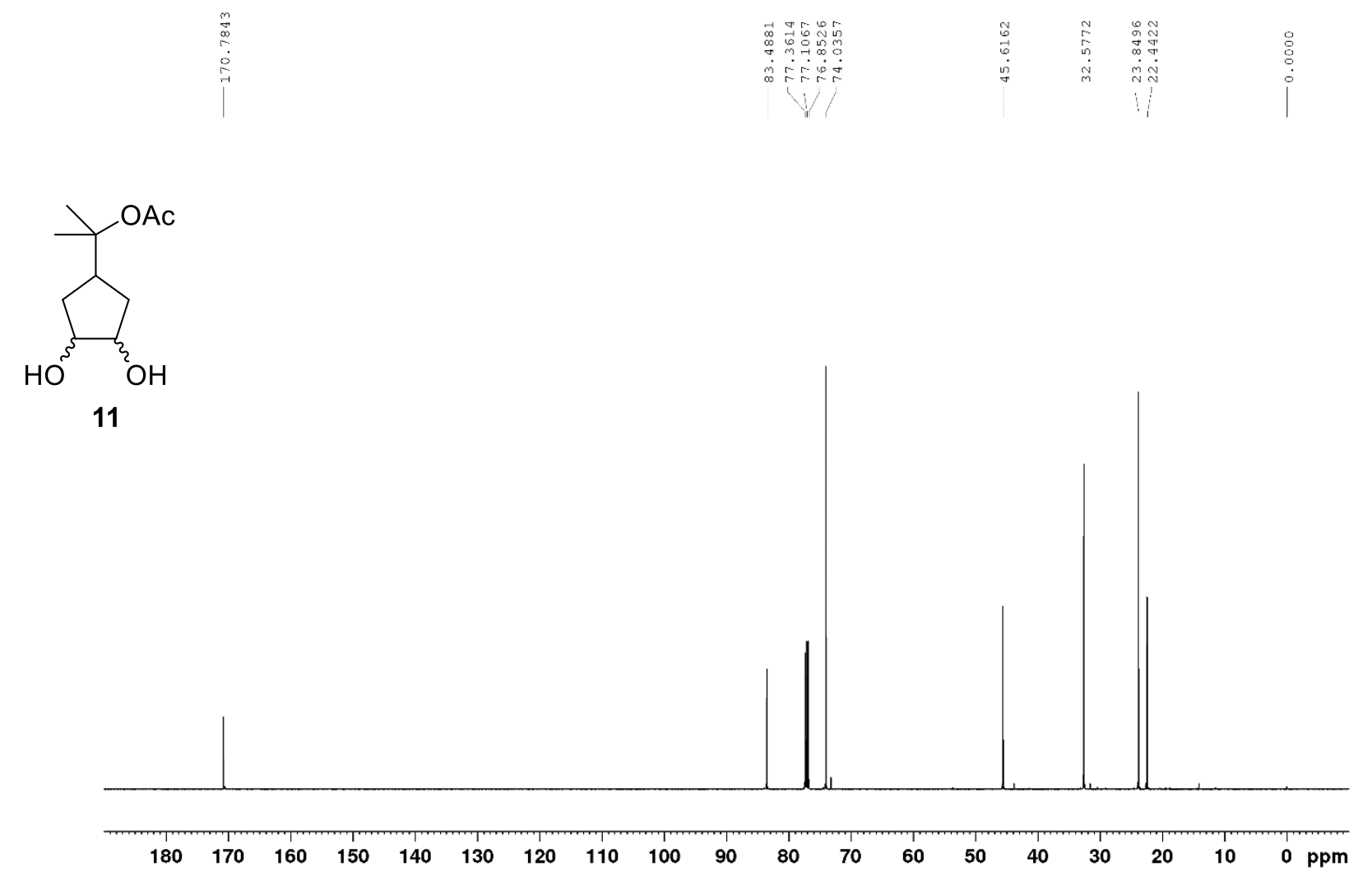


$\overbrace{\mathrm{O}}^{\mathrm{O}}$

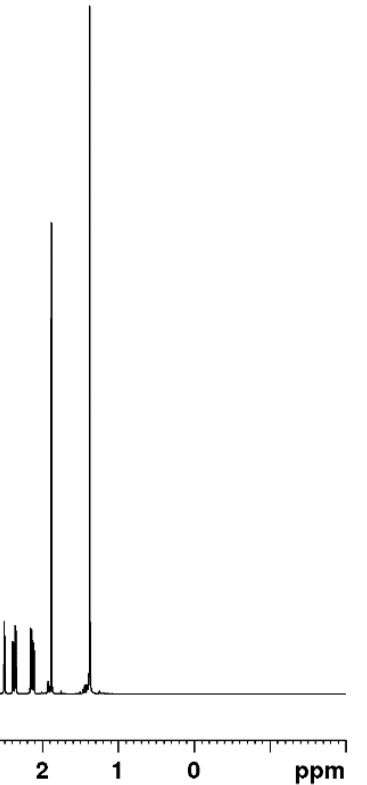

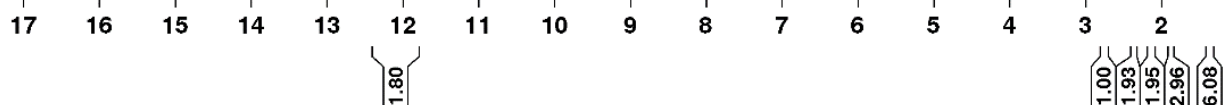




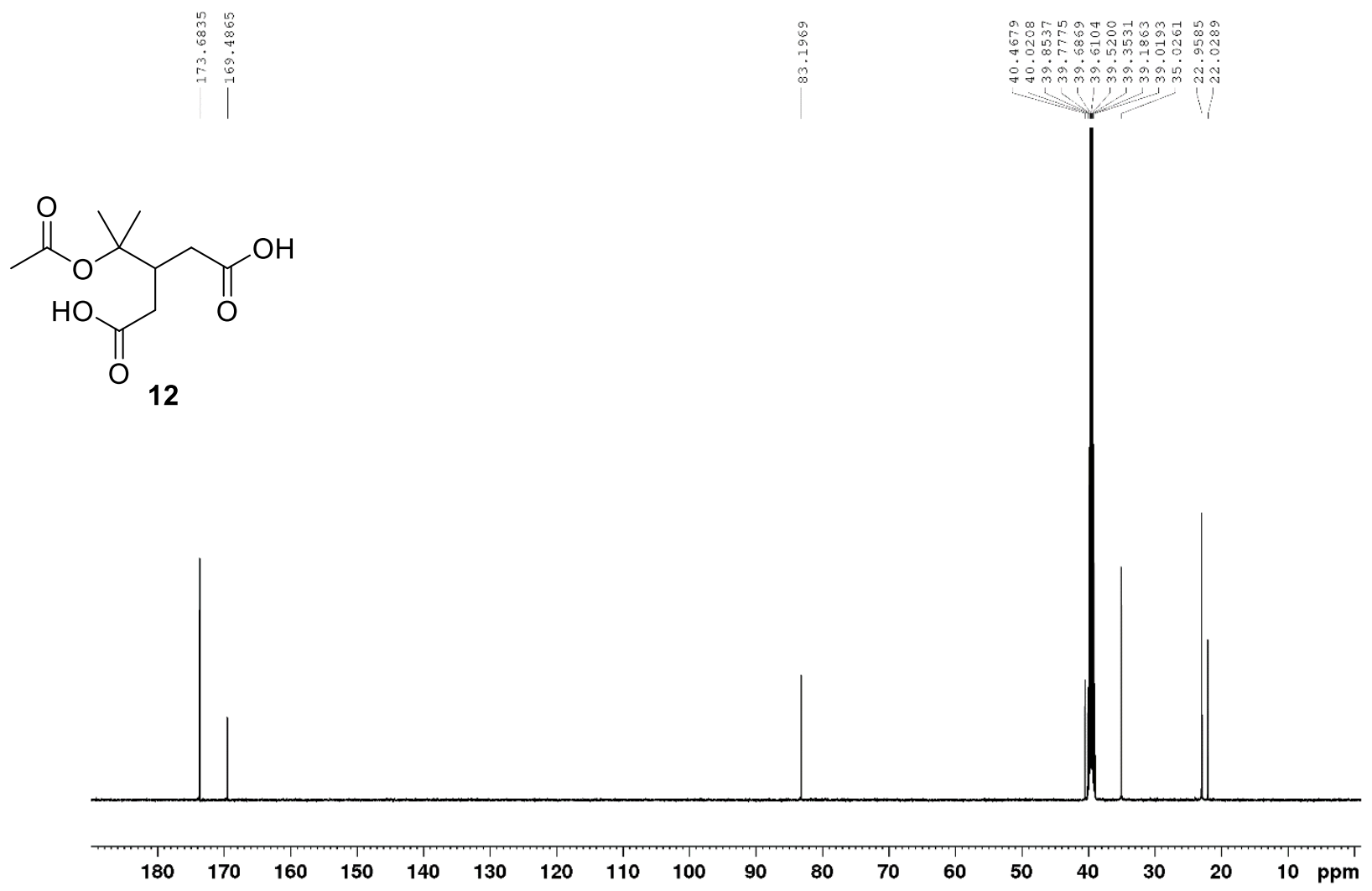




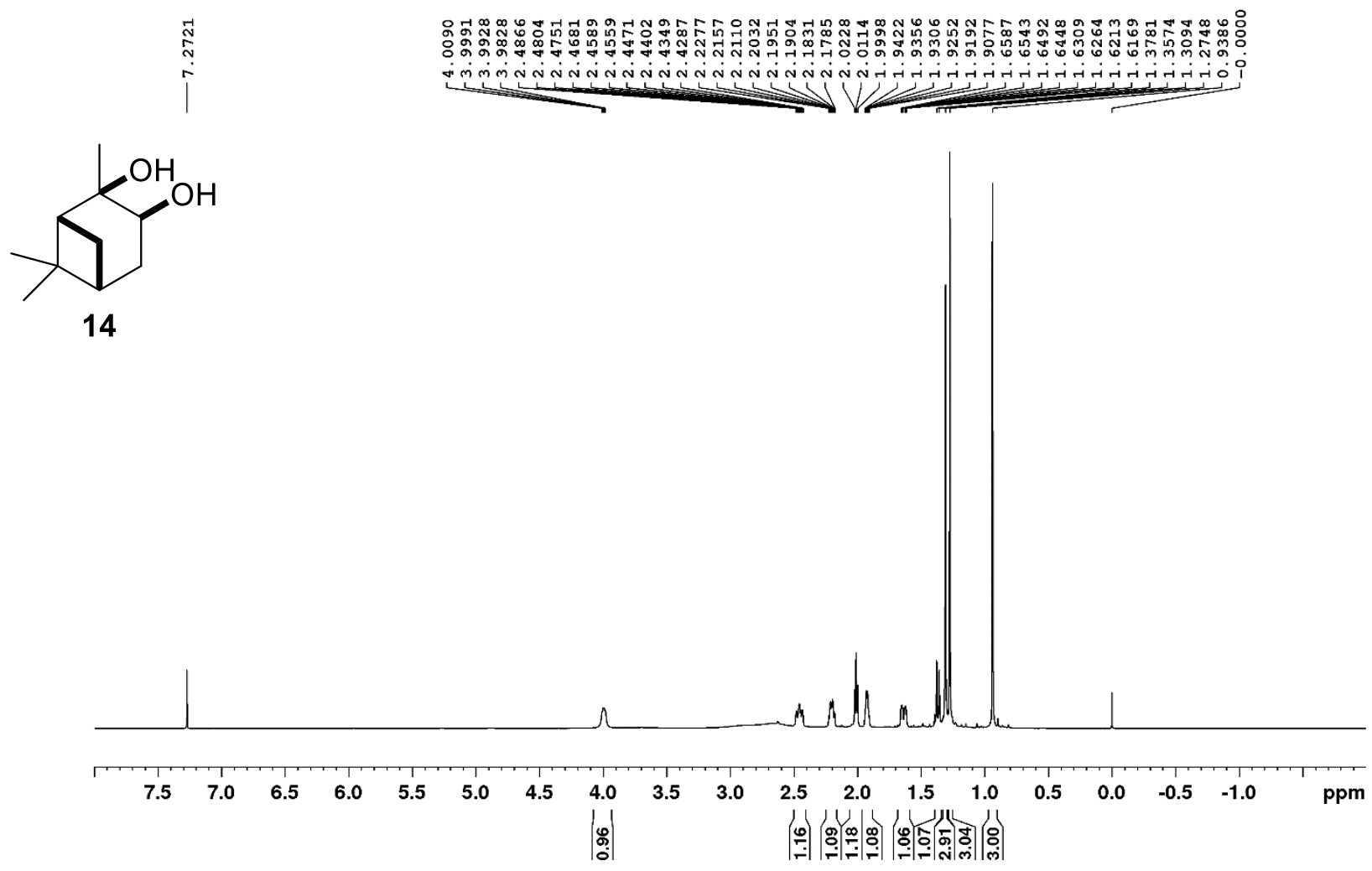




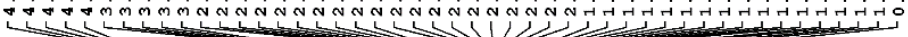

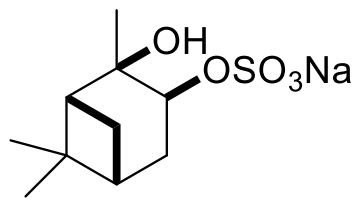

15

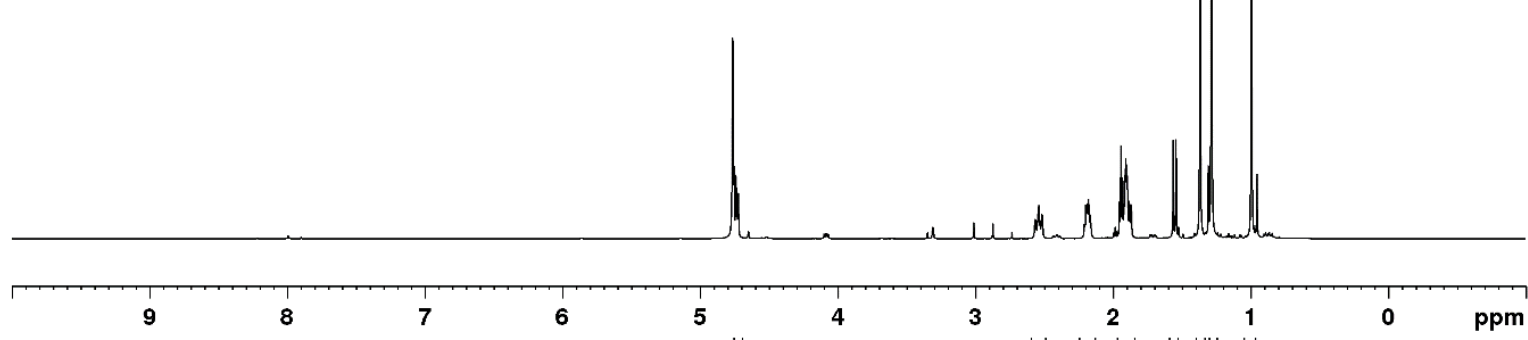

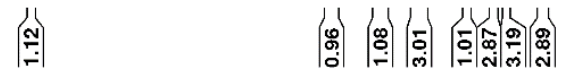



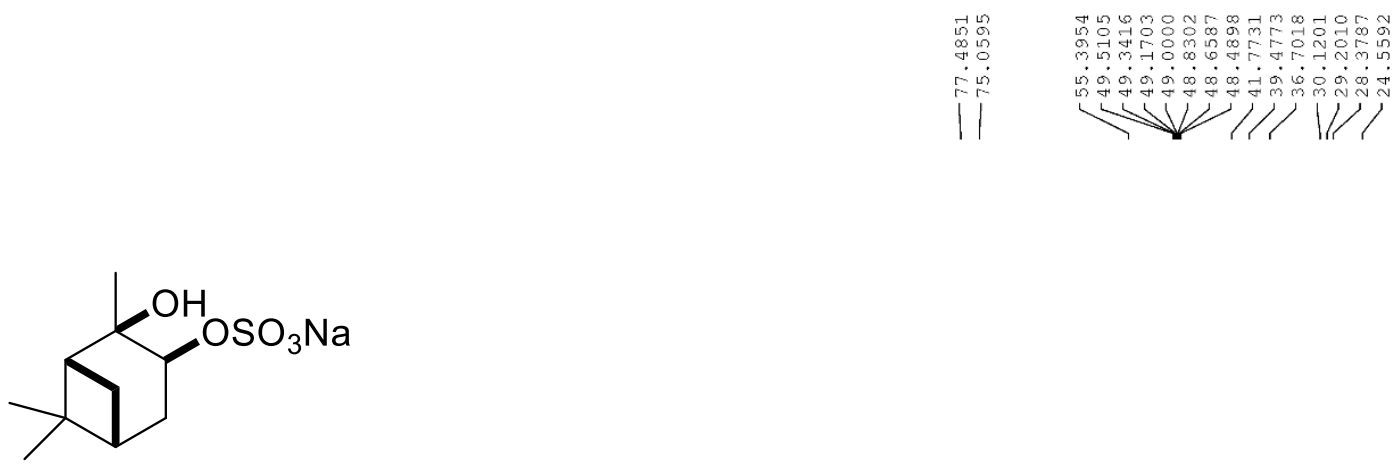

15

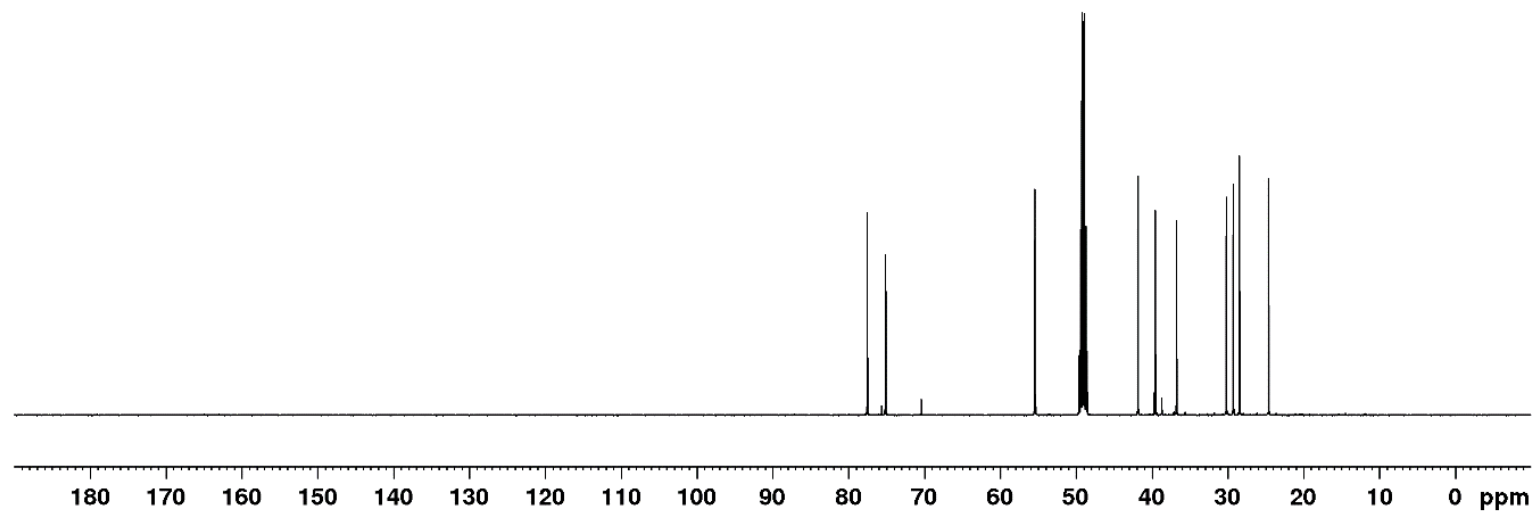




\section{Particle Transmission Efficiencies of Thermal Denuder}

The particle size distribution and size-resolved particle transmission efficiencies at set temperatures of $25^{\circ} \mathrm{C}, 40{ }^{\circ} \mathrm{C}, 60{ }^{\circ} \mathrm{C}$, and $100{ }^{\circ} \mathrm{C}$ with an effective RT of $60 \mathrm{~s}$ are demonstrated in Figs. S1 (a) and (b). In general, no substantial change in sized-resolved particle number concentration was perceived at aforementioned set temperatures. The particle transmission efficiencies remained the same for particles larger than $25 \mathrm{~nm}$, as large particles possess small diffusivities. Regardless of the set temperature, particles smaller than $25 \mathrm{~nm}$ exhibited lower transmission efficiencies than particles larger than $25 \mathrm{~nm}$ which might be due to diffusional losses inside the heating section of thermal denuder. Similar observations were also noted in other studies. ${ }^{12-14}$

The particle size distribution and transmission efficiency at the effective RTs of $60 \mathrm{~s}$ and $70 \mathrm{~s}$ and a set temperature of $100^{\circ} \mathrm{C}$ are demonstrated in Figs. S1 (c) and (d). The particle size distribution and sized-resolved transmission efficiency were nearly same at effective RTs of 60 s and $70 \mathrm{~s}$. 

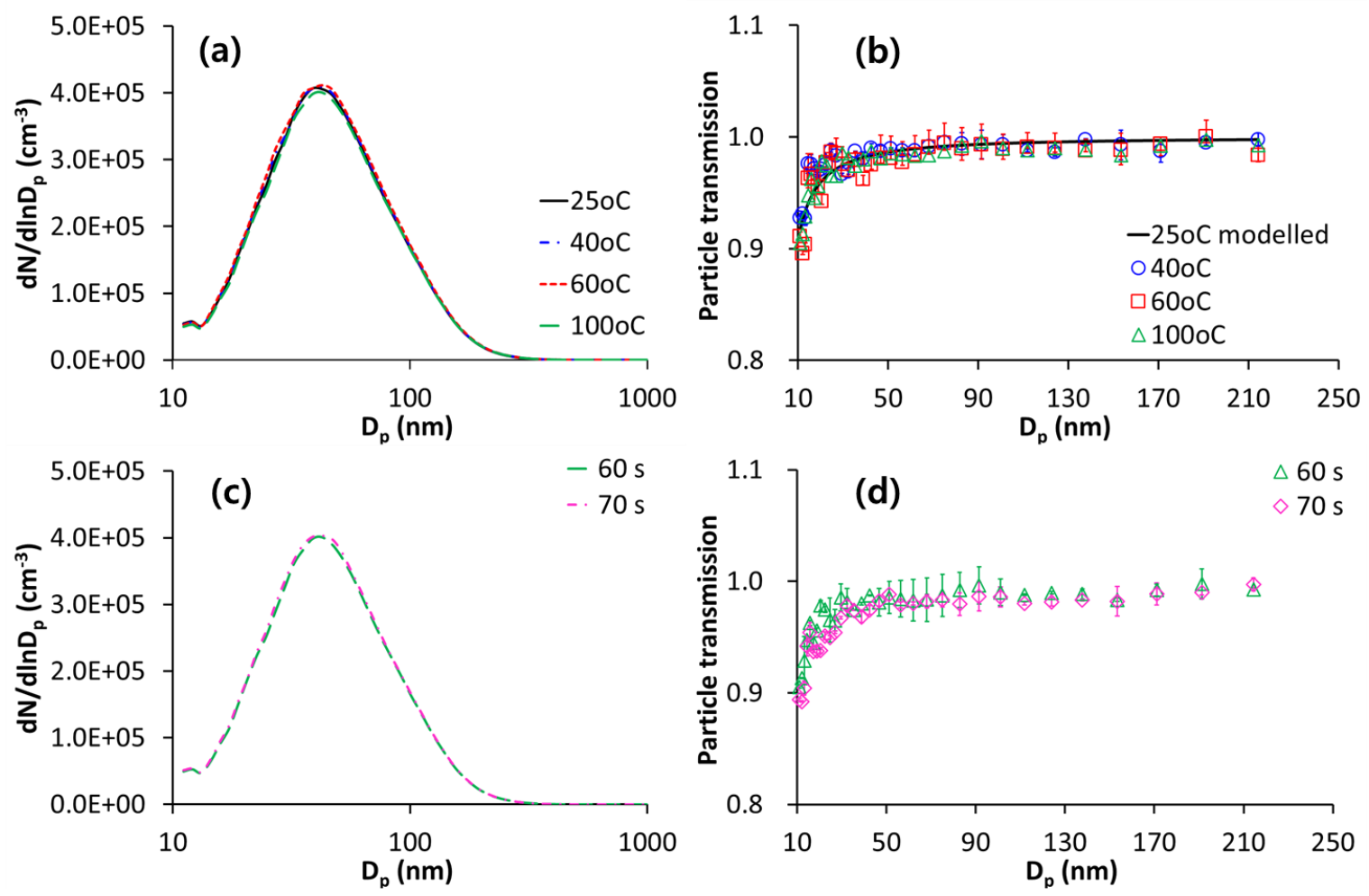

Fig. S1. For $\mathrm{NaCl}$ at set temperatures of $25^{\circ} \mathrm{C}, 40^{\circ} \mathrm{C}, 60^{\circ} \mathrm{C}$, and $100^{\circ} \mathrm{C}$ and effective RT of 60 $\mathrm{s}$, (a) particle size distribution and (b) size-resolved particle transmission efficiency. Theoretical diffusional losses of particles at reference temperature of $25{ }^{\circ} \mathrm{C}$ is represented by solid line. For $\mathrm{NaCl}$ at effective RTs of $60 \mathrm{~s}$ and $70 \mathrm{~s}$ and set temperature of $100^{\circ} \mathrm{C}$, (c) particle size distribution and (d) size-resolved particle transmission efficiency. 


\section{References}

(1) Dette, H. P.; Qi, M.; Schröder, D. C.; Godt, A.; Koop, T. Glass-Forming Properties of 3Methylbutane-1,2,3-Tricarboxylic Acid and Its Mixtures with Water and Pinonic Acid. Journal of Physical Chemistry A 2014, 118 (34), 7024-7033. https://doi.org/10.1021/jp505910w.

(2) Claeys, M.; Iinuma, Y.; Szmigielski, R.; Surratt, J. D.; Blockhuys, F.; Van Alsenoy, C.; Böge, O.; Sierau, B.; Gómez-González, Y.; Vermeylen, R.; Van Der Veken, P.; Shahgholi, M.; Chan, A. W. H.; Herrmann, H.; Seinfeld, J. H.; Maenhaut, W. Terpenylic Acid and Related Compounds from the Oxidation of $\alpha$-Pinene: Implications for New Particle Formation and Growth above Forests. Environmental Science and Technology 2009, 43 (18), 6976-6982. https://doi.org/10.1021/es9007596.

(3) Krapcho, A. P.; Larson, J. R.; Eldridge, J. M. Potassium Permanganate Oxidations of Terminal Olefins and Acetylenes to Carboxylic Acids of One Less Carbon. Journal of Organic Chemistry 1977, 42 (23), 3749-3753. https://doi.org/10.1021/jo00443a026.

(4) Rajagopalan, A.; Lara, M.; Kroutil, W. Oxidative Alkene Cleavage by Chemical and Enzymatic Methods. Advanced Synthesis and Catalysis 2013, 355 (17), 3321-3335. https://doi.org/10.1002/adsc.201300882.

(5) Iinuma, Y.; Böge, O.; Keywood, M.; Gnauk, T.; Herrmann, H. Diaterebic Acid Acetate and Diaterpenylic Acid Acetate: Atmospheric Tracers for Secondary Organic Aerosol Formation from 1,8-Cineole Oxidation. Environmental Science and Technology 2009, 43 (2), 280-285. https://doi.org/10.1021/es802141v.

(6) Schmidt, A. K. C.; Stark, C. B. W. TPAP-Catalyzed Direct Oxidation of Primary Alcohols to Carboxylic Acids through Stabilized Aldehyde Hydrates. Organic Letters 2011, 13 (16), 4164-4167. https://doi.org/10.1021/ol2014335.

(7) Spannring, P.; Bruijnincx, P. C. A.; Weckhuysen, B. M.; Gebbink, R. J. M. K. A MetalFree, One-Pot Method for the Oxidative Cleavage of Internal Aliphatic Alkenes into Carboxylic Acids. RSC Advances 2013, 3 (18), 6606-6613. https://doi.org/10.1039/c3ra40324f.

(8) Gomes, M.; Antunes, O. A. C. Upjohn Catalytic Osmium Tetroxide Oxidation Process: Diastereoselective Dihydroxylation of Monoterpenes. Catalysis Communications 2001, 2 (6-7), 225-227. https://doi.org/10.1016/S1566-7367(01)00038-3.

(9) Hanessian, S.; Wang, X.; Ersmark, K.; Del Valle, J. R.; Klegraf, E. Total Synthesis and Structural Revision of the Presumed Aeruginosins 205A and B. Organic Letters 2009, 11 (18), 4232-4235. https://doi.org/10.1021/o1901702k.

(10) Wang, Y.; Ren, J.; Huang, X. H. H.; Tong, R.; Yu, J. Z. Synthesis of Four MonoterpeneDerived Organosulfates and Their Quantification in Atmospheric Aerosol Samples. Environmental Science and Technology 2017, 51 (12), 6791-6801. https://doi.org/10.1021/acs.est.7b01179.

(11) Zhu, Y.; Zhao, X.; Zhu, X.; Wu, G.; Li, Y.; Ma, Y.; Yuan, Y.; Yang, J.; Hu, Y.; Ai, L.; Gao, Q. Design, Synthesis, Biological Evaluation, and Structure-Activity Relationship (SAR) Discussion of Dipeptidyl Boronate Proteasome Inhibitors, Part I: Comprehensive Understanding of the SAR of $\alpha$-Amino Acid Boronates. Journal of Medicinal Chemistry 2009, 52 (14), 4192-4199. https://doi.org/10.1021/jm9005093.

(12) Wehner, B.; Philippin, S.; Wiedensohler, A. Design and Calibration of a Thermodenuder with an Improved Heating Unit to Measure the Size-Dependent Volatile Fraction of Aerosol Particles. Journal of Aerosol Science 2002, 33 (7), 1087-1093. https://doi.org/10.1016/S0021-8502(02)00056-3. 
(13) Huffman, J. A.; Ziemann, P. J.; Jayne, J. T.; Worsnop, D. R.; Jimenez, J. L. Correction to "Development and Characterization of a Fast-Stepping/Scanning Thermodenuder for Chemically-Resolved Aerosol Volatility Measurements." Aerosol Science and Technology 2008, 43 (3), 273-273. https://doi.org/10.1080/02786820802616885.

(14) Saha, P. K.; Khlystov, A.; Grieshop, A. P. Determining Aerosol Volatility Parameters Using a 'Dual Thermodenuder' System: Application to Laboratory-Generated Organic Aerosols. Aerosol Science and Technology 2015, 6826 (July 2015), 00-00. https://doi.org/10.1080/02786826.2015.1056769. 